\title{
EXALTAÇÃO DO MESTIÇO: A INVENÇÃO DO ROTO CHILENO
}

Horacio Gutiérrez*

Resumo: O artigo examina o processo de transformação de um personagem mestiço chileno de origem urbano, o roto, em tipo nacional representativo da chilenidade. Como figura mestiça, descendente de espanhóis e indígenas, foi desprezado no século XIX à luz das teorias raciais em voga. Mas no início do século XX surgem autores que descobrem nele qualidades, tentando elevá-lo a símbolo da nação.

Palavras-chave: Mestiçagem; Identidades; Roto chileno.

\section{Mestizo exaltation: the invention of Chilean roto}

\begin{abstract}
This article examines the process of transformation of the roto, a Chilean personage of urban origin, into a national symbol of chilenidade. As a descendent of Spaniards and Natives, the mestizo was rejected in the Nineteenth century in the light of racial theories that were current at that time. However, at the beginning of the Twentieth century it seemed that intellectuals discovered the mestizo qualities, and tried to raise its status as one of a national symbol.
\end{abstract}

Key Words: Mestizaje; Identities; Chilean roto.

No século XIX a América Latina caracterizou-se pela convivência de raças e grupos étnicos de diversas origens, bem como pela instabilidade política e o confronto de variados projetos de nação, criando-se um clima propício para a recepção e discussão de teorias explicativas sobre seu desenvolvimento e seu destino. Enfrentavam-se as duras tarefas que nasciam com o término das lutas de Independência e que se relacionavam com a construção dos Estados nacionais.

Naquele contexto surgiram diversos pensadores que trataram de examinar a América Latina daquele momento, identificando o que no seu entender constituíam os dilemas do presente e os rumos do futuro. Propuseram-se projetos para uma América Latina nova que fosse capaz de superar os males que a afligiam, incorporando as reformas sociais, econômicas e políticas consideradas

\footnotetext{
* O presente texto faz parte de pesquisa mais ampla sobre identidades chilenas que contou com bolsa de produtividade do CNPq.
} 
fundamentais. O que atormentava a América Latina e que reformas era necessário empreender? Uma das vertentes em voga na explicação do atraso foi a discussão do papel das raças e o lugar que cada uma deveria ter na construção da nação e de sua identidade. As implicações da mestiçagem e os defeitos e virtudes do mestiço, foram especialmente debatidos.

\section{Contexto latino-americano}

Para o darwinismo social, assim como para o organicismo spenceriano, a América Latina era cenário de uma luta desenfreada de grupos sociais por subsistir e vítima de incontáveis 'doenças orgânicas'. Para Gobineau, que residiu no Brasil e logrou ampla influência nos demais países da América, a mestiçagem resultante da escravidão de africanos provocava a degenerescência da raça branca, corrompendo à nação na sua pureza de sangue; o destino final seria a barbárie. Darwin, em contrapartida, tinha dúvidas sobre a real perversidade da mestiçagem para o futuro das nações, e Spencer, ao contrário, concluía que o mestiço era um elemento instável, incapaz de fundar civilizações sólidas e criativas. O discurso racial no século XIX foi dominante no pensamento social, político e literário, e esteve presente nos escritos de quase todos os intelectuais americanos de renome. As referências teóricas foram européias, em geral francesas, inglesas e italianas, com poucas variações: Arthur de Gobineau, Gustave Le Bon, Cesare Lombroso, Henry Thomas Buckle, Oswald Spengler e outros.

Em harmonia com o pensamento racial europeu, o pensamento latinoamericano mostra uma preocupação sistemática pela origem multiétnica de seus povos que, ao estilo de seus inspiradores, era visto como fonte de contradições e obstáculo para a criação de uma nação e de uma identidade nacional. A construção dessa identidade seria incompatível com a diversidade étnica, religiosa ou lingüística. Unicamente os povos com características homogêneas seriam capazes de criar uma nação. Assim, há um esforço permanente dos intelectuais em, por um lado, homogeneizar a nação, seja no discurso, seja na prática e, por outro, em tratar que essa homogeneização se realize, no que à variável raça se refere, de forma positiva e fecunda.

Na segunda metade do século XIX o discurso racial se tornou obsessivo. Ingressava-se na fase do 'racismo científico'. Depois das Independências haviam ocorrido diversas tentativas nos novos países por definir identidades nacionais que os diferenciassem das potências colonizadoras. Nesse esforço a literatura romântica mostrou-se particularmente criativa. O problema indígena foi especialmente debatido e a solução requeria assinalar o que fazer com eles e qual deveria ser seu lugar no perfil de nação que se desejava. O debate voltaria com grande força por ocasião das comemorações do primeiro centenário das Independências, quando as 
identidades nacionais foram reavaliadas e velhos arquétipos questionados. Foi o momento dos 'explicadores' das nações e dos grandes ensaístas.

As avaliações do Centenário ocorreram num clima intelectual de auge das teorias racistas. O chamado racismo científico tinha-se transformado em fins do século XIX em paradigma das ciências humanas que poucos latino-americanos ousaram contestar ou ignorar, definindo uma sorte de limites dentro dos quais as explicações giraram. Por trás estava a idéia de evolução linear dos povos, percurso pelo qual todos passariam e que seria similar em todos os lugares. O evolucionismo, em voga na Europa desde meados do século XIX, propunha encontrar um nexo entre os diferentes tipos de sociedades, e procurava encontrar leis comuns explicativas do desenvolvimento das civilizações ao longo da História. ${ }^{1}$ Haveria então sociedades mais avançadas e sociedades mais atrasadas. O estágio de civilização poderia depender de diversos fatores, e interessava descobri-los. É o racismo científico que encontra a explicação mais aceita nessa conjuntura, atribuindo as diferenças às variáveis raça e meio ambiente. Neste contexto, e abstraindo os muitos matizes existentes, o branco tornara-se portador de civilização; o negro e o índio representavam entraves; e o mestiço figuraria como símbolo de degenerescência.

\section{O pensamento racial chileno}

Meio e raça passaram a ser, para muitos autores chilenos de fins do século XIX e inícios do século XX, categorias que permitiam definir e entender a realidade. Foi assim com Francisco A. Encina (1874-1965), historiador prolífico e entusiasta da raça branca, tido como o principal historiador chileno do século XX. Sua obra principal, a monumental Historia de Chile, em 20 volumes (1940-52), exerceu uma assombrosa influência na historiografia chilena, e suas opiniões a respeito do passado, das instituições e dos personagens históricos, tornaram-se senso comum na academia e no ensino escolar. Para Encina a pedra angular da história chilena é a peculiaridade étnica de seu povo, muito diferente do restante da América. Os conquistadores que chegaram ao Chile traziam em suas veias uma alta proporção de sangue germânico ('gótico'), e é o sangue, diz Encina, o que determina a psicologia de uma raça. A excepcionalidade do país devera-se ao elemento godo superior de sua classe alta e média, que só não era dotada de energia vital maior, por causa da mestiçagem com a população indígena que corrompera o elemento superior, tendo tido por este motivo que recomeçar a ascensão a partir de níveis mais baixos da escala da evolução social.

Imaginativo e nacionalista, Encina inspirara-se nas análises étnicas de seu conterrâneo Nicolás Palacios (1854-1911), médico, agricultor remediado como seu admirador, e igualmente fantasioso, mas com uma diferença fundamental: Palacios defendia a figura do mestiço, não o identificando com degenerescência. Sua obra 
principal data de 1904, Raza chilena, livro divisor de águas no uso da categoria raça no Chile. Trata-se de uma obra volumosa com quase 800 páginas, de enorme sucesso na época, alcançando diversas edições e uma repercussão considerável entre intelectuais e simples leitores. "Rico em idéias", era no entanto "pobre em coerência e solidez conceitual e histórica". ${ }^{2}$ Estava "equivocado naquela parte em que expõe suas teorias raciais", mas era "valoroso e exato em sua parte crítica e programática em relação aos problemas econômicos e sociais do Chile. Sua publicação foi um patriótico sinal de alarma frente às injustiças sociais imperantes e uma apaixonada defesa das classes populares". ${ }^{3}$

Em linguagem direta e pouco elaborada, propunha-se a provar ao menos três teses: 1) Chile compunha-se de elementos raciais particulares, um tipo étnico definido e único no mundo, muito distante da raça ibero-latina; 2) Chile possuía um território agrícola escasso e era necessário aproveitá-lo e ocupá-lo melhor, mas nunca com colonização e imigração inferior como a latina; 3) Chile passava por uma séria crise e uma das razões principais era a imagem negativa que a oligarquia dominante possuía da classe popular, do roto. ${ }^{4}$

Palacios em sua obra encanta-se com o roto chileno enquanto protótipo, exaltando sua figura. O roto seria o tipo proletário que nascia com o movimento operário, em particular do mundo mineiro das províncias do Norte Grande, berço do socialismo, anarquismo e comunismo. Mas Palacios tinha uma postura aristocratizante e anti-socialista. Identificava o socialismo com as raças judia e latina, que desprezava e considerava inferiores. Seu livro é a tentativa de demonstrar a superioridade racial do roto, cuja segregação social ocorreria pela ignorância e decadência da classe média e alta, contaminada pela raças latinas que se infiltraram na imigração. O roto, que considerava a base do povo chileno, ter-se-ia formado pelo cruzamento da raça gótica (do sul da Suécia, conquistadora da Espanha, onde formara um 'enclave', sendo este o grupo que depois conquistara o Chile) e araucana (também superior porque patriarcal). Em suma: o mestiço, que constituía a maioria do povo chileno, seria uma raça superior. ${ }^{5}$

Nas palavras de Senén Palacios, seu irmão Nicolás "encarnou um anelo nacional, abrindo novos horizontes ao orgulho pátrio ao lhe dar uma base de nobreza étnica". ${ }^{6}$ Isto explicaria o sucesso do livro, em que pesem as demonstrações inconsistentes, provas históricas insustentáveis e argumentações contraditórias. Não exagerava em seu julgamento se levarmos em conta a cálida recepção do livro na época, surpreendentemente redescoberto na década de 1980, durante a ditadura de Pinochet, quando é reeditado por diversas editoras, permanecendo meses a fio entre os dez mais vendidos, a pesar de sua extensão.

O roto chileno seria enaltecido por outros autores contemporâneos, como Roberto Hernández (1929) e Luis Durand (1942), e celebrado pela poesia popular, 
a música e as artes plásticas. A tese do mestiço degenerado do século XIX dera lugar no Chile, e também em muitos outros países da América Latina, a uma reação ufanista, de exaltação do mestiço, nas primeiras décadas do século XX. Em muitos países o mestiço passa a ser o símbolo da nacionalidade, fonte da verdadeira cultura nacional, o portador dos valores mais profundos e perenes. Essa posição significava o abandono final do mito da superioridade da raça branca, mas a custa da criação de um novo mito, o da superioridade do mestiço.

\section{$O$ roto, símbolo nacional}

A obra prima na construção histórica da figura do roto deve-se ao ensaísta e jornalista Roberto Hernández (1877-1966) que publica, em 1929, El Roto Chileno, examinando o assunto em mais de 600 páginas. ${ }^{7}$ O livro é um hino em louvor àquele personagem mestiço e uma legítima peça do gênero invenção das tradições. Foi este autor quem talvez melhor trabalhou essa figura no desejo de transformála em tipo nacional representativo da chilenidade. "Não há ainda", diz, "um livro da natureza do presente", entre outras razões, "porque a maioria dos escritores nacionais crê rebaixar-se indo até as camadas humildes do povo".

O cosmopolitismo em voga teria debilitado as tradições nacionais, afirma, e gerado um menosprezo inconseqüente,

(...) primeiro pelo índio da epopéia araucana, que hoje agoniza em miseráveis redutos à sombra de seus coigües milenares, e em seguida pelo roto da cidade e dos campos, envilecido não apenas com o álcool, mas com os efeitos de uma propaganda tenaz e dissolvente, que repugna a sua natureza íntima ${ }^{8}$.

O roto, ficamos sabendo por ele, não foi uma figura forjada nas lides mineras e nas guerras do século XIX, ou na indústria urbana dos inícios do XX, mas remonta ao período colonial, mais precisamente ao século XVI. A Guerra de Arauco, travada com os espanhóis durante a conquista, constituiria sua arena de gestação. No roto "palpita a herança araucana, o exemplo varonil dos aborígines que, amantes da liberdade e de sua terra, mantiveram um embate de séculos contra o inimigo estrangeiro". Segundo Hernández, fora o próprio Alonso de Ercilla, no poema épico La Araucana (1569-89), o autor do mais completo e acabado retrato dos "rotos primitivos" ":

Son de gestos robustos, desbarbados, bien formados los cuerpos y crecidos, espaldas grandes, pechos levantados, recios miembros, de nervios bien formados ágiles, desenvueltos, alentados, amistosos, valientes, atrevidos, 
duros en el trabajo y sufridores

de fríos mortales, hambres y calores.

Ercilla, entretanto, não estava descrevendo os rotos, mas os índios araucanos. E é interessante notar que o autor escolhe como marco zero do roto o momento de contato dos indígenas com os espanhóis, e não o período anterior, tido por igualmente heróico, narrado por Ercilla nas estrofes seguintes, e que registra a resistência dos araucanos frente ao Império Inca, que não conseguira subordinálos. Hernández valoriza também em seu texto a Pedro de Valdivia, “o intrépido conquistador" e seus exércitos de espanhóis que combatiam os indígenas. Assim, a descrição do "roto primitivo" que retira de Ercilla, embora referida aos araucanos, poderia, imaginamos, ser aceita mais facilmente como alegoria do "roto moderno", já que ele descende de araucanos, ainda que não apenas deles, pois também nascera dos valentes espanhóis.

As guerras coloniais teriam significado para o roto instâncias preciosas para se "esmerar e enobrecer em matéria de qualidades guerreiras", passando pelo teste final e a consagração definitiva no século XIX, durante as guerras de Independência, da Confederação Peruano-boliviana (1836-39) e da Guerra do Pacífico (1879-83). Nesta última conflagração "o roto sargento Aldea no combate de Iquique e o roto sargento Rebolledo no cume do San Juan foram como símbolos do que era capaz o povo armado do Chile no mar e em terra firme". Curiosamente o autor omite o capitão Arturo Prat, alçado na época a herói máximo chileno da Guerra do Pacífico, e que se imolara precisamente no combate naval de Iquique, favorecendo com o gesto a vitória frente à marinha peruana. Mas Prat, sendo da classe média, branco, e tendo logo a seguir conquistado o posto de patrono da marinha chilena, poderia ser chamado de roto?

Concluída a jornada militar, "o roto abandona o rifle para ser operário da indústria, para empunhar o combo, a pá ou a barreta na pampa salitreira, ou então unir os bois ao jugo nas tarefas agrícolas, enquanto canta com ingênuo desenfado", diz o autor, versos como os seguintes ${ }^{10}$ :

Yo no me muero por naide,

naide se muera por mí,

solo me saco mi maire

y solo $m$ 'hei de morir.

Nesta transformação ocupacional emergem as demais características do roto, antes menos visíveis: além de ser um valente e vitorioso nas guerras contra o inimigo, o roto é ingênuo, bem-humorado e brincalhão. E mais:

(...) depois de ter comprometido a gratidão nacional, esse ser anônimo na vida, o será também no túmulo, na vala comum dos despojos humanos, onde não se registra sequer um mísero 
epitáfio. Era a sorte reservada ao filho das multidões, ao 'soldado desconhecido', ao exército sem nome, mas heróico, que dá força às nações. A pátria é seu único bem; o nome de seu regimento é sua bandeira. ${ }^{11}$

Ou seja, o roto, além de valente, vitorioso, ingênuo e brincalhão, é também alguém anônimo, sem nome, sem rosto, possivelmente sem propriedades, sem a educação formal que lhe permita escrever ou falar corretamente, e cujo único bem e norte na vida é a pátria, pela qual luta, desloca-se e se entrega se necessário. Pode-se concluir que é alguém a inteira disposição das autoridades, disponível para qualquer atividade que elas qualifiquem de patriótica, e que não reclama nem reivindica nada. Essa livre disposição de sua pessoa decorre seguramente do fato de não ter inserção social, nem domicílio fixo, ou de não pertencer a uma classe ou camada social organizada que possa defendê-lo, nem ter família para protegêlo ou dar-lhe ao menos uma sepultura digna. Aparentemente é um personagem que tampouco sente falta dessa sociabilidade, nem a busca ou a quer. Poder-se-ia sintetizar dizendo que o roto "é tudo abnegação, tudo sacrifício, e cujo orgulho maior, em seu fanatismo pela pátria, é poder chamar-se roto chileno".

As características do roto em Hernández coincidem com um excluído, um marginal ou, mais propriamente, não encaixam em nenhum grupo ou pessoa real. Sua descrição não combina com a de um camponês, de um operário nem com o trabalhador nortista do salitre. O perfil tampouco se identifica com o gaucho argentino, o bandeirante brasileiro, nem o pioneiro norte-americano, pintados em geral como portadores de valores liberais - a liberdade ou a democracia - e que em suas marchas disseminavam esses valores mundo afora. Talvez o roto fosse portador de valores mais conservadores como hierarquia e obediência, embora salte a dúvida de se esses valores não seriam antes reflexo do pensamento do autor do que do personagem que pretende retratar.

Uma coisa é clara: para o autor a palavra roto não indicaria apenas uma pessoa maltrapilha, mas um tipo nacional chileno, representativo da nação, que existira desde sempre. Ou melhor, desde o século XVI, quando araucanos e espanhóis se encontraram na região de Arauco e travaram batalhas antológicas, engendrando o roto, essa figura mestiça que se tornaria com o correr do tempo majoritária na população.

Assim, o mérito principal de Roberto Hernández foi seu esforço de transformar o roto em tipo nacional chileno, no mestiço típico. Trata-se da tentativa mais séria, dentre os autores de sua época, de avançar nessa direção. Restaria saber onde está esse roto. $\mathrm{O}$ autor não se incluiu nele e claramente se coloca fora do padrão descrito. O roto, na concepção do autor, é evidentemente um outro, estando além de seu círculo, e ao que parece também longe geograficamente. A atitude do autor corresponde à de um pesquisador atento que observa de um mirante o objeto 
de seu estudo. E este certamente não pertence a seu tempo, mas ao passado, pois se lamenta que em sua época roto tenha virado um termo pejorativo, e se tenha perdido infelizmente "a sua primeira acepção", positiva. De fato, seu livro é a tentativa de salvar a figura do roto do esquecimento porque "os costumes nacionais estão-se perdendo e correm o risco de desaparecer para sempre".

\section{Novas faces do roto}

Nas décadas de 1940 e 1950 novos ensaios apareceram de exaltação do roto. Sem a extensão dos livros de Palacios e Hernández, dois artigos inseridos em coletâneas foram importantes pela repercussão que alcançaram, sem dúvida devido à fama de seus autores. Luis Durand (1895-1954), romancista a essa altura de renome nacional, publica em 1942 a coleção de ensaios Presencia de Chile, cujo manuscrito havia sido agraciado com o Primeiro Prêmio no Concurso Literário do Centenário de Santiago. ${ }^{12}$ Um dos textos, "Apreciación del roto", estende-se na defesa do personagem. O outro autor, Oreste Plath, publica seu texto na década de 1950 .

Durand lamenta que o conceito de roto se tenha degradado, passando a representar "os maus costumes, os piores hábitos", um erro evidente, avalia, que é preciso corrigir com uma correta apreciação histórica. O primeiro roto teria sido don Pedro de Valdivia, o conquistador espanhol do Chile, que comandou "aquele punhado de homens audazes e decididos" desafiando as inclemências dos desertos no norte, e realizando façanhas "dignas de Homero". Numa terra pobre como a chilena teve que desafiar raças belicosas e indomáveis, "disputar seus territórios palmo a palmo, em duras campanhas cheias de sacrifícios e penalidades". Os índios não estavam dispostos a se deixar dominar e ofereciam batalhas contínuas, sem recessos. Os espanhóis então foram obrigados a viver com as armas em punho e nesse contexto "não é difícil imaginar" lhes faltara a roupa que, desgastando-se, não tinham como repor. Quem afirmou isso, argumenta o autor, foram cronistas coloniais, citando alguns. Assim, Pedro de Valdivia, sem alternativa, empreende viagem ao Peru com o objetivo primordial de trazer roupas e tecidos. Chegando a Lima, a indumentária que vestia, forrada de remendos, causara péssima impressão, sendo apelidado de roto, mas não se importara com isso. Os peruanos continuaram a chamar os chilenos de rotos, expressão perpetuada pela boca de viajantes e que se generalizou depois para designar o povo.

O roto, para Durand, é o representante autêntico do povo, não incluindo, aparentemente, nessa representação, às classes abonadas e proprietárias. Insurge-se contra aqueles que desprezam o roto, isto é, as classes populares, e que não querem ver nele qualidades, mas apenas defeitos. O roto descende "de duas raças fortes e orgulhosas" e "é herdeiro de um grande espírito e de uma grande inteligência 
que se desenvolve de forma assombrosa apenas encontra meios de cultivá-la". Os primeiros mestiços chilenos, afirma, foram filhos de Valdivia que recebeu 500 mulheres indígenas, todas solteiras e donzelas, em troca da liberação do chefe indígena Michimalonco, ao qual aprisionara. Com elas teve filhos, os primeiros rotitos.

Além de atribuir ao roto qualidades heróicas e bom humor constante, vê nele outras virtudes que comenta com mais vagar. No roto confluem "o engenho e vivacidade andaluza". "É respeitoso, disciplinado e amante de cumprir seus compromissos", capaz das maiores generosidades e ansioso de aventuras, como Dom Quixote, muito diferente do espírito utilitário e calculista de Sancho Pança. "Sua lealdade e fidelidade são proverbiais, incapaz de cometer uma traição, mas é altivo e até insolente quando se sente atropelado, burlado ou quando the roubam o que honradamente lhe pertence". ${ }^{13}$

Caracteriza-se o roto também pela resignação, um valor positivo, e exemplo dessa atitude foi a reação de grandeza que teve frente às conseqüências desastrosas que provocou no Chile a crise mundial de 1929. Aquela tragédia "não abateu seu moral, não derribou seu conceito de homens conhecedores do papel que lhes corresponde dentro da coletividade." Os rotos não se lançaram

(...) à rua para erigir-se numa ameaça de vidas, nem de bens. Em seus corações não germinou o ódio, nem pretenderam perturbar a ordem estabelecida com revoltas, nem tumultos de rua. Trataram de ser homens frente a sua desgraça e souberam esperar dias melhores com fé e estoicismo verdadeiramente

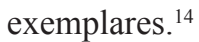

Ser arruaceiro e rebelde são às vezes defeitos infligidos ao roto, equivocadamente. São nódoas que pertencem na verdade a elementos indesejáveis que se infiltram entre os rotos como "bichos parasitários", mas que os rotos são os primeiros em repelir. Já o fato de ser atrevido é um defeito que não pode ser atribuído apenas ao roto, mas "é uma herança do conquistador que deixou não só a todos os chilenos, mas a todos os povos ibero-americanos".

Para Durand, o roto de qualidade não está em decadência. "Seu espírito esforçado e heróico é possível que hoje esteja adormecido, mas conserva-se intacto e latente." Basta constatar que "o drama escuro de sua vida miserável nos campos e cidades não apagou seu sorriso, nem acabou com seu humorismo de boa lei." E "um povo que sabe rir ainda que se sinta órfão de todos os prazeres da vida, não pode estar em decadência." 15

Outro autor de renome que saiu em defesa do roto foi Oreste Plath (19071996), folclorista que escreveu o texto "Epopeya del 'roto' chileno" incluído na coletânea Autorretrato de Chile, lançada em 1957. ${ }^{16}$ 
Para Plath o roto é um selo de chilenidade e para compreendê-lo é necessário conhecer o meio físico em que atua, ou seja, empapar-se da geografia chilena. Cada zona ecológica determina um tipo particular. Daí que não exista um protótipo único. As variáveis telúricas influenciam e modificam a anatomia, a fisiologia e a psicologia dos indivíduos, produzindo adaptações. A conformação geográfica do Chile, com tantos climas, gestou, assim, vários tipos de rotos.

Do índio herdou a valentia, a propensão ao risco, a determinação e a lealdade. E também a agilidade, a destreza, a pujança, e essa virilidade sem par "cantada por seu inimigo em La Araucana". Do espanhol aprendeu o gosto pelo jogo, a bebida e a superstição. Inegável é a influência andaluza, patente em traços como o humor, a graça e a astúcia.

Essas marcas de caráter foram em alguns casos realçadas e em outros atenuadas, pela geografia. Muito diferentes são o roto marinheiro, milico, pampino, minerador, carrilano, carregador e bandido. São sete tipos altamente representativos aos quais o autor reserva a maior parte do artigo, descrevendo-os em pormenores.

Tanto no texto de Durand, como no de Plath, a imagem do roto que transparece é a de que se está analisando um personagem simbólico (ou vários), fincado na nacionalidade. A descrição não corresponde à de um psicólogo que lista traços da personalidade de um indivíduo, ou à de um economista que relaciona as ocupações dos estratos D e E da população. Ou seja, ambos autores tentam descolar a acepção vulgar de roto com pessoa maltrapilha, reforçando o significado de personagem representativo de algo, seja o povo, as classes trabalhadoras, a chilenidade, como fizeram antes Palacios e Hernández. Mas ambos autores percebem, assim como Palacios e Hernández, que se trata de um pleito, quer dizer, não há, no momento em que cada um escreve, uma aceitação tranqüila de que o roto seja um emblema. Sim há, nos quatro autores, a convicção de que o foi em algum momento do passado, tradição que hoje se estaria perdendo.

\section{$O$ roto esculpido}

Esforços por sacralizar o roto no passado efetivamente existiram. A tentativa mais concreta deu-se no século XIX. Em comemoração à batalha de Yungay, ocorrida em 1839 durante a Guerra contra a Confederação Peruano-boliviana (1836-39), fora erguido, 50 anos depois, em outubro de 1888, durante o governo de Balmaceda, um Monumento ao Roto Chileno numa praça de periferia em Santiago, a Plaza Yungay. A estátua, representando um camponês com camisa e calças arregaçadas, segurando um fuzil na mão direita, era uma homenagem ao soldado desconhecido, mas valente e patriota, que participara na conflagração mencionada. A guerra foi impopular desde o início e o recrutamento complicado, pois a opinião 
pública e a população em geral, nela incluída os rotos, esteve inicialmente contra o conflito, não entendendo seus motivos. Após alguns reveses afrontosos, o exército chileno, no entanto, vence a guerra na referida batalha de Yungay, em 20 de janeiro de 1839.

A estátua ao Roto Chileno deve-se ao escultor Virginio Arias (1855-1941) e não decorreu, conforme as fontes, de iniciativa oficial, mas do próprio escultor. Inicialmente a obra chamou-se "Héroe del Pacífico" e com esse nome foi apresentada por Arias ao Salão de Paris em 1882, obtendo dois anos depois medalha de ouro na Exposición Nacional de Santiago, no Chile. A Municipalidad de Santiago, tendo em vista essa trajetória, decide comprar a escultura, destinando-a à Plaza Yungay. ${ }^{17}$ Note-se que o nome original da obra faz menção não aos heróis da Guerra contra a Confederação, mas aos da Guerra do Pacífico, ocorrida também contra Peru e Bolívia, mas em 1879-83. A inauguração da estátua de um metro e meio de altura, colocada sobre um pedestal de elevação generosa, aconteceu em 7 de outubro de 1888 .

Nesse ano, 1888, decretou-se o dia 20 de janeiro como o Dia del Roto Chileno, em comemoração à Batalha de Yungay, celebrando-se a efeméride a partir de 1889 e até hoje. Todo ano nesse dia há cerimônia oficial na Plaza Yungay, aos pés da Estátua do Roto, com presença de autoridades, grupos folclóricos e Banda do Exército. No evento discursa o prefeito de Santiago, depositam-se oferendas, hasteia-se a bandeira nacional e se entoa o Hino de Yungay, aprendido por todas as crianças na escola:

\author{
Cantemos la gloria \\ del triunfo marcial \\ que el pueblo chileno \\ obtuvo en Yungay. ${ }^{18}$
}

Com letra de Ramón Rengifo, o Hino, de várias estrofes e cadência militar, fora musicado por José Zapiola em 1839, ao calor dos festejos populares pelo triunfo chileno na guerra contra a Confederação Peruano-boliviana, alcançando sucesso instantâneo. Conta-se que fora a seu compasso que os batalhões chilenos marcharam novamente ao norte durante a Guerra do Pacífico. No Hino, entretanto, não é usado o vocábulo roto nem se faz menção a nenhum roto em particular.

A pesar dos esforços, a figura do roto não vingara no século XIX como emblema da chilenidade e na percepção da elite ilustrada continuou significando apenas um maltrapilho, uma pessoa com vestimenta esfarrapada, além de grosseira e sem berço.

Os dicionaristas da época corroboram essa afirmação, sendo cristalina a definição do termo. No Diccionario de Chilenismos de Zorobabel Rodríguez, um dos primeiros publicados sobre o assunto, lançado em 1875, figura o termo roto com o seguinte significado: 
Esta palabra no es propiamente un chilenismo, porque una de sus acepciones castizas es andrajoso, zarrapastroso. Téngase, sí, como una peculiaridad de nuestro uso el servirnos de aquella voz para designar a la gente de última clase, a la misma cuyos individuos son llamados cholos en el Perú, y léperos en México. ${ }^{19}$

Outro dicionário famoso, o de José Toribio Medina, publicado em 1928 e intitulado Chilenismos, também registra a palavra, com a seguinte acepção: "Roto, ta. (Del latín ruptus). Argentina y Perú. Fam. despectivo. Apodo con que se designa al chileno. // (En Chile, al hijo del pueblo)". ${ }^{20}$

Quer dizer, em nenhum dos dois dicionários figura a acepção de roto associada a um tipo nacional representativo da chilenidade. A instalação do monumento e do dia do roto não foram suficientes. A escultura ficaria como homenagem aos soldados de uma guerra vitoriosa, estendida mais tarde aos participantes da Guerra do Pacífico, e ainda depois projetada a um passado mais longínquo, um tributo também aos rotos que lutaram na guerra da independência. Em termos genéricos, tornar-se-ia com o passar do tempo uma estátua de homenagem às camadas populares da nação.

\section{Rotos, nunca mais}

Se não foi no século XIX que ocorrera a elevação do roto a emblema nacional, tampouco foi no século XX, em que pese o esforço dos ensaístas antes comentados. Mas por outro lado, o roto como personagem tampouco desaparecia do imaginário nacional, e vez por outra retornava triunfante na pena de algum intelectual solidário com as causas populares, que o enchia de qualidades, e lhe outorgava novamente status de símbolo. Cansado com as ressurreições, o crítico literário Raúl Silva Castro arremeteu iracundo, em mais de uma oportunidade, contra essas tentativas, e principalmente decide emprestar o peso de seus argumentos e de seu nome para erradicar de uma vez por todas essa história do roto, injuriosa, em sua opinião.

Silva Castro, catedrático universitário, escrevia colunas e resenhas para os principais jornais do país. Em texto de 1941, republicado depois na coletânea de sua autoria Estampas y Ensayos, ${ }^{21}$ investe contra a existência de uma caricatura chamada Verdejo, criada em 1931 e transformada logo a seguir em revista cômica regular com muita aceitação popular. Verdejo representa ao povo chileno? pergunta contrariado.

Verdejo era homem magro, baixinho, boca desdentada, roupas remendadas, chapéu furado, mas simpático e de frases pícaras e mordazes. Conforme Salinas, Verdejo “constituiu a representação clássica do 'roto' chileno entre os anos 30 e 
60". ${ }^{22}$ Para Silva Castro trata-se de uma criação infamante, e ofensivo é querer representar o povo chileno com uma figura maltrapilha, suja, fétida, sem orgulho próprio, infra-humana, falando corriqueiramente frases de periferia e de bordel, porque não tem educação. O povo chileno, afirma categórico, não pode se reconhecer num exemplar dessa espécie depois de haver criado consciência de seus direitos, de haver conquistado voz e voto e, vivendo em melhor situação que ontem, quererá certamente vestir roupas mais adequadas que as de esse personagem vergonhoso.

Verdejo é nocivo para o Chile, sentencia o autor:

Dentro das fronteiras nacionais é nocivo porque eleva à categoria de doutrina nacional o abandono, a desídia e a sujeira; porque cria e fomenta o complexo de inferioridade, e porque enfaixa numa só estampa, arbitrária, a imagem muito mais variada que o povo chileno oferece à vista de todos. ${ }^{23}$

O distintivo, hoje, no Chile, é o predomínio da classe média, acrescenta. E Verdejo não faz parte "dessa classe média que triunfa e se abre passo com brio vigoroso. Se é possível falar em classes, pertence ele apenas às turbas de subúrbio, triste refugo da sociedade, que se alimenta antes de vícios do que de pão". Assim, urge eliminar Verdejo de nosso horizonte e "reduzi-lo ao que deve ser, ou seja, a uma caricatura sem raiz alguma no espírito chileno". Porque acaso, "poderíamos fazer uma pátria grande e feliz se elevássemos o dito plebeu de Verdejo à categoria de norma? (...) Esse Verdejo que não acredita em nada e nada espera, não pode ser compatriota nosso, partícipe de nosso sangue, porque em suas atitudes parece ter perdido até a estatura de homem". ${ }^{24}$

As reflexões de Silva Castro foram em vão. O roto continuou no imaginário chileno e na polêmica, século XX adentro, até hoje. Apesar de combatido e 'desmascarado', o arquétipo do roto não desapareceu. A sua persistência, no entanto, possivelmente se deva menos a ensaístas como Durand e Plath, lidos afinal apenas por letrados, e mais a sua difusão por meio de historietas em quadrinhos do tipo Verdejo. Décadas depois, em meados de 1950, apareceria outra revista do gênero, com mais sucesso ainda, Condorito, que permanece em circulação até o presente, com impressão internacionalizada, distribuída em vários países. Condorito já não é mais um mestiço, mas um condor, a ave nacional chilena, humanizado. O roto antropomorfo nasce vestindo poncho, mas a pouco andar o troca por uma camiseta vermelha, a cor da seleção chilena de futebol, mas mantém a ojota nos pés e as calças remendadas.

$\mathrm{Na}$ disputa pela simbologia nacional o roto perde no século $\mathrm{XX}$ para o huaso, uma figura rural, mestiça, com poncho sobre os ombros, chapéu caprichado, calçando sapatos ou botas com esporas, pronto para montara cavalo, impecavelmente vestido, nunca remendado. Manteve, no entanto, as características de picardia 
do roto. O huaso converteu-se ao longo do século XX em símbolo nacional do Chile e figura de exportação, assim como a dança e a música que lhe pertencem, a cueca, tornou-se oficial, por decreto supremo, em 1979. Todo 18 de setembro, dia da independência do país, nas festas oficiais e populares comemorativas da data, aparecem huasos autênticos e, principalmente, fictícios, dançando cueca e vestidos a caráter.

Hobsbawm detectou que algumas tradições nunca existiram, foram inventadas, e o caso do roto chileno mostra uma invenção. ${ }^{25}$ Podemos agregar que a pesar de verídico, o fato de ter sido inventada, forjada, não significa que a posteriori, uma vez arraigada e aceita sobre falsas bases, não tenha se transformado em uma tradição verdadeira, só que agora com outro mito de origem e outros marcos temporais de construção. Desmascará-la ajuda a desnaturalizar a tradição original, mas esse fato por si só não elimina a tradição, como pode ser comprovado com o roto chileno.

\section{Considerações finais}

Tanto a tese do século XIX que menosprezara o mestiço, como a do século $\mathrm{XX}$ que o enaltecera, parecem revelar enormes dificuldades para lidar com a diversidade. Coloca-se em ambas como pano de fundo o axioma que parece guiar a busca da identidade nacional no Chile e outros países: a idéia de que para existir uma identidade nacional é necessário haver homogeneidade, neste caso racial, sendo a diversidade incompatível com a possibilidade de existência de uma identidade. Lembre-se que essa homogeneidade fora muito buscada também em relação a outras variáveis como a língua nacional, religião, território, e história pátria comum.

Se essa homogeneidade não existisse, ela deveria ser inventada. No século XIX a homogeneização foi proposta e tentada com diversas medidas: promoção de imigração internacional de populações concebidas como superiores; estímulo à mistura de raças para diluir, a longo prazo, a presença de grupos considerados inferiores; e inclusive políticas que contemplaram o extermínio de populações indesejadas ou rebeldes à assimilação e ao despojo (ocupação da Araucanía, no Chile; Campanha do Deserto, na Argentina, etc.). No século XX restringir-se-iam muito as possibilidades de propor ou implementar medidas desse tipo, principalmente as mais radicais, e a homogeneização racial teria sido promovida menos pela prática, e mais pela teoria: criar-se-iam personagens mestiços representativos do nacional, tipos-síntese da nação; no caso do Chile, o roto e o huaso, um de origem urbana, o outro rural. Ou seja, na época da exaltação do mestiço, a idéia da necessidade de homogeneidade racial teria permanecido em vigor.

Assim, a aceitação de uma sociedade plural, com diversidade racial e 
cultural, seria um fenômeno, no Chile e em geral na América Latina, muito recente, remontando apenas às últimas décadas do século XX. Permaneceria como desafio, no entanto, a construção de identidades nacionais compatíveis com uma democracia racial.

\section{NOTAS}

I ORTIZ, R. Cultura brasileira e identidade nacional. São Paulo: Brasiliense, I994; SILVEIRA, Renato da. Os selvagens e a massa: papel do racismo científico na montagem da hegemonia ocidental. Afro-Ásia, $\mathrm{n}$. 23, 1999, p. 89-145.

2 GAZMURI RIVEROS, C. Testimonios de una crisis: Chile, 1900-1925. Santiago: Editorial Universitaria, 1980, p. 19.

3 JOBET, j. C. Los precursores del pensamiento social de Chile. Santiago: Editorial Universitaria, 1955-56, v. 2, p. 101 .

4 Ver considerações de ARANCIBIA CLAVEL, P. Recepción y crítica a Raza Chilena: los comentarios de Miguel de Unamuno. Dimensión Histórica de Chile, n. 3, 1986, p. 63-98.

5 Cf. GAZMURI RIVEROS, C. Notas sobre la influencia del racismo en la obra de Nicolás Palacios, Francisco A. Encina y Alberto Cabero. Historia (Santiago), v. 16, 1981 , p. 225-247.

6 PALACIOS, S. Nicolás Palacios: recuerdos íntimos. Trata-se da introdução a PALACIOS, Nicolás. Raza Chilena. Santiago: Antiyal, 1986, v. I, p. 9-35.

7 HERNÁNDEZ C., R. El roto chileno: bosquejo histórico de actualidad. Valparaíso: Imprenta San Rafael, 1929.

8 Idem, pg. 5-6

9 Citado por HERNÁNDEZ, op.cit., p. I I. Ver ERCILLA Y ZÚÑIGA, A. de. La Araucana. Madri: Aguilar Editor, 1946, p. 68.

10 HERNÁNDEZ, op. cit., p. 9.

II Idem, pg. 9

12 DURAND, L. Apreciación del roto. In: Presencia de Chile. Santiago: Nascimento, 1942, p. 99- 135.

13 Idem, p. 107- 108.

14 Idem, p. $11|-| 13$.

15 Idem, p. I22- 123.

16 PLATH, O. Epopeya del 'roto' chileno. In: GUZMÁN, N. (org.). Autorretrato de Chile. Santiago: ZigZag, 1957, p. 133-147.

17 Informações do portal oficial do Consejo de Monumentos Nacionales de Chile, na internet, assinadas por Liisa Flora Voionmaa:

http://www.monumentos.cl/monumento.php?monumento_id = 10744

I8 BAEZA, M. Cantares de Chile. Santiago: Editorial del Pacífico, 1972, p. 217.

19 RODRÍGUEZ, Z. Diccionario de chilenismos. Santiago: Imprenta de El Independiente, I875, p. 427.

20 MEDINA, J. T. Chilenismos: apuntes lexicográficos. Santiago: Universo, 1928, p. 328.

2 I SILVA CASTRO, R. Estampas y ensayos. México: Fondo de Cultura Económica, 1968. O texto em questão é "Verdejo y anti-Verdejo", p. 103-106. Na mesma coletânea consta também o artigo "iNo más roto chileno!", p. I I7-I 20.

22 SALINAS CAMPOS, M. La vida y las aventuras cotidianas de Juan Verdejo según da revista Topaze en 1938. Revista de Ciencias Sociales, Iquique, n. 16, 2006, p. 65-82.

23 SILVA CASTRO, op. cit. p. 104.

24 Idem, p. 105.

25 "Introdução" a HOBSBAWN, E. \& RANGER, T. (orgs.). A invenção das tradições. São Paulo: Paz e Terra, 1997. 